\title{
Analisis Non Performing Loan (NPL) Pada Bank Pembangunan Daerah Yang Terdaftar Di Bursa Efek Indonesia Sebelum Dan Selama Pandemi Covid-19
}

\author{
Aldi Akbar ${ }^{\mathbf{1}}$, Karyadi ${ }^{2}$, Budi Rustandi Kartawinata ${ }^{3}$ \\ ${ }^{12}$ Komputer Akuntansi, Politeknik Piksi Ganesha, Indonesia \\ ${ }^{3}$ Administrasi Bisnis, Telkom University, Indonesia \\ *Email: aldi.akbar@piksi.ac.id \\ Doi : https://doi.org/10.37339/jurnal e-bis.v5i1.537
}

Diterbitkan oleh Politeknik Dharma Patria Kebumen

Info Artikel

Diterima :

2021-04-12

Diperbaiki :

2021-04-22

Disetujui :

2021-06-02

\begin{abstract}
ABSTRAK
Pandemi Covid-19 yang menerpa Indonesia sangat berdampak pada berbagai sektor tak terkecuali jasa keuangan khususnya perbankan. Salah satu indikator yang digunakan dalam mengukur kinerja perbankan adalah non performing loan (NPL). Penelitian ini bertujuan untuk mengetahui kinerja bank pembangunan daerah yang terdaftar di Bursa Efek Indonesia terkait dampak pandemi Covid-19 menggunakan proxy NPL. Hasil penelitian menunjukkan bahwa bank pembangunan daerah pun ikut terdampak imbas dari pandemi Covid-19 ini yang mana NPL tiap bank cenderung bertambah dibandingkan sebelum pandemi Covid-19. Penelitian ini juga menghasilkan temuan lain dari sisi mikroekonomi berupa perbandingan NPL dengan ROA serta dari sisi makroekonomi berupa perbandingan NPL dengan inflasi, pertumbuhan PDB dan Tingkat Pengangguran Terbuka.
\end{abstract}

Kata Kunci:pandemi Covid-19, NPL, bank pembangunan daerah

\section{ABSTRACT}

The Covid-19 pandemic that hit Indonesia has had a profound impact on various sectors including financial services, especially banking. One of the indicators used in measuring banking performance is a non-performing loan (NPL). This study aims to determine the performance of regional development banks listed on the Indonesia Stock Exchange related to the impact of the Covid-19 pandemic using an NPL proxy. The results showed that regional development banks were also affected by the Covid-19 pandemic, in which the NPL of each bank tended to increase compared to before the Covid-19 pandemic. This research also produces other findings from a microeconomic perspective in the form of a comparison of NPL with ROA and from a macroeconomic perspective in the form of a comparison of NPL with inflation, GDP growth and the Open Unemployment Rate.

Keywords: write down 3-5 keywords related to the content of the paper 


\section{PENDAHULUAN}

Pandemi Covid-19 yang melanda Indonesia pertama kali terjadi di bulan Maret 2020 dan hal ini merupakan imbas dari mewabahnya penularan Covid-19 yang bermuasal dari kota Wuhan di Cina sejak bulan Desember 2019 (Dzulfaroh, 2020). Dampak yang diakibatkan dari pandemi ini bukan hanya terciptanya krisis kesehatan yang telah memperparah terjadinya krisis politik dan sosial, memperburuk ketimpangan yang ada dan secara tidak proporsional mempengaruhi segmen masyarakat yang paling rentan (Rose-Redwood et al., 2020) namun lebih dari itu menjalar hingga ke sektor perekonomian dengan cakupan nasional bahkan global (Yamali, 2020; Abdi, 2020; Pak et al., 2020).

Masifnya penyebaran virus ini bahkan memaksa organisasi kesehatan dunia, WHO, pada akhir Januari 2020 menetapkan virus corona ini sebagai Public Health Emergency of International Concern (Organization, n.d.) dan puncaknya pada tanggal 11 Maret 2020 diumumkan bahwa wabah ini sebagai Pandemic Global (Dong et al., 2020).

International Monetary Fund (IMF) menetapkan tahun 2020 sebagai The Great Lockdown pada bulan April 2020 dan ekonomi dunia di tahun 2020 diprediksi lebih buruk dari The Great Depression 1929 dan Global Financial Crisis 2008 (Prayogo, 2020; McKibbin \& Vines, 2020). Menurut catatan IMF kerugian yang ditimbulkan pandemi Covid-19 ini sebesar 12 triliun dolar AS atau sekitar Rp 168.000 triliun dengan kurs acuan Rp 14.000 per dolar AS, pertumbuhan ekonomi dunia diprediksi - 4,4 \% (Gopinath, 2020). Selain IMF lembaga dunia lainnya turut memprediksikan pertumbuhan ekonomi yang negatif di antaranya Bank Dunia (World Bank) sebesar -5,2 \% dan The Organisation for Economic Co-operation and Development (OECD) berkisar -7,6 \% hingga -6 \% (Prayogo, 2020).

McKibbin \& Vines (2020) dalam penelitiannya menyebutkan bahwa dalam lima tahun mendatang masih akan terjadi defisit fiskal seperti yang ditunjukkan pada tabel 1 .

Tabel 1. Perubahan defisit fiskal terhadap \% GDP (sumber: McKibbin \& Vines (2020)

\begin{tabular}{|c|c|c|c|c|c|c|}
\hline Country/region & 2020 & 2021 & 2022 & 2023 & 2024 & 2025 \\
\hline USA & -0.10 & -1.32 & -0.26 & 0.81 & 1.16 & 1.06 \\
\hline Japan & -0.66 & -0.67 & 0.15 & 0.65 & 0.72 & 0.60 \\
\hline Germany & -0.21 & -1.43 & -0.40 & 0.62 & 1.02 & 0.79 \\
\hline United Kingdom & -0.22 & -0.80 & -0.40 & 0.14 & 0.51 & 0.52 \\
\hline France & -0.27 & -0.70 & 0.20 & 0.90 & 1.08 & 0.91 \\
\hline Italy & 4.98 & 1.41 & 1.16 & 0.57 & 0.91 & 0.72 \\
\hline Rest of Euro Zone & 5.73 & 1.72 & 1.49 & 0.94 & 1.50 & 1.29 \\
\hline Canada & -0.24 & -0.48 & -0.06 & 0.22 & 0.37 & 0.41 \\
\hline Australia & -0.44 & -0.60 & 0.05 & 0.31 & 0.29 & 0.24 \\
\hline Rest of OECD & 5.85 & 1.83 & 1.28 & 0.85 & 1.60 & 1.30 \\
\hline South Korea & -0.73 & -0.47 & 0.03 & 0.26 & 0.31 & 0.36 \\
\hline Turkey & 5.60 & 2.48 & 1.24 & 0.07 & 0.24 & 0.15 \\
\hline China & -0.31 & -0.69 & -0.21 & 0.06 & 0.10 & 0.10 \\
\hline India & 5.76 & 2.35 & 1.21 & 0.31 & 0.59 & 0.52 \\
\hline Indonesia & 5.70 & 2.47 & 1.46 & 0.36 & 0.45 & 0.31 \\
\hline Other Asia & 5.88 & 3.06 & 1.92 & 0.55 & 0.63 & 0.53 \\
\hline Mexico & 5.57 & 2.93 & 1.66 & 0.29 & 0.30 & 0.20 \\
\hline Argentina & 6.69 & 1.70 & 0.81 & 0.12 & 0.72 & 0.58 \\
\hline Brazil & 6.17 & 1.67 & 1.17 & 0.54 & 0.89 & 0.72 \\
\hline Russia & 5.93 & 2.44 & 1.48 & 0.40 & 0.61 & 0.46 \\
\hline Saudi Arabia & 4.17 & 1.33 & 1.31 & 0.62 & 0.88 & 0.78 \\
\hline South Africa & 6.48 & 2.62 & 1.65 & 0.82 & 1.01 & 0.87 \\
\hline Rest of world & 5.91 & 2.78 & 1.43 & 0.21 & 0.51 & 0.42 \\
\hline Rest of OPEC & 5.32 & 2.56 & 1.12 & -0.02 & 0.24 & 0.17 \\
\hline World total & 2.28 & 0.35 & 0.46 & 0.45 & 0.72 & 0.62 \\
\hline
\end{tabular}


Amerika, Inggris, Jerman dan beberapa negara Eropa lainnya pada tahun 2022 mulai menunjukkan pertumbuhan yang positif meskipun masih di bawah 2\%. Di Asia, negara Cina, Korea Selatan dan Jepang akan mengalami pertumbuhan yang positif juga pada transisi tahun 2022-2023. Yang menarik justru Indonesia, di tahun 2020 perubahan fiskalnya masih di angka $5,70 \%$ namun dalam lima tahun mendatang justru akan mengalami penurunan meski tidak sampai negatif. Tentunya bagi Indonesia hal ini harus diantisipasi dengan berbagai kebijakan fiskal yang lebih tepat sasaran di antaranya berupa Perppu Nomor 1 Tahun 2020. Dalam perppu tersebut secara garis besar mengatur segala hal terkait kebijakan dan stabilitas keuangan negara imbas pandemi Covid-19 termasuk mengenai perpajakan, pembiayaan dan kebijakan keuangan daerah (Purwanto, 2020). Manakala kebijakan tersebut dilaksanakan beriringan dengan penerapan protokol kesehatan yang tertib dan disiplin maka tidak mustahil prediksi Asian Development Bank (ADB) bahwa perekenomian Indonesia di 2021 bisa tumbuh $5,2 \%$ (ADB, 2020).

Chen \& Yeh (2021) dalam publikasinya menyebutkan bahwa satu bulan sebelum dan sesudah WHO mengumumkan Covid-19 sebagai pandemi global beberapa industri dari 49 industri di Amerika langsung terdampak. Hal ini terlihat dari nilai akumulasi pendapatan yang tidak normal atau cumulative abnormal return (CAR). Tabel 2 berikut menunjukkan sepuluh industri di AS yang paling terdampak dari pandemi global tersebut.

Tabel 2. Industri di AS yang terdampak pandemi global.
Sumber: Chen \& Yeh (2021)
\begin{tabular}{clc}
\hline No. & Industry Name & CAR $(-30,+30)$ \\
\hline 1 & Textiles & -49.63 \\
2 & Printing and Publishing & -40.34 \\
3 & Construction & -31.41 \\
4 & Aircraft & -30.73 \\
5 & Banking & -25.17 \\
6 & Business Supplies & -24.60 \\
7 & Precious Metals & -24.40 \\
8 & Real Estate & -23.69 \\
9 & Entertainment & -23.13 \\
10 & Restaurants, Hotels, Motels & -20.36 \\
\hline
\end{tabular}

Dari sisi likuiditas industri di AS yang paling terdampak pandemi global berturut-turut adalah kelompok industri produk tahan lama dan pakaian (Consumer Durables \& Apparel), industri produk rumah tangga dan pribadi (Household \& Personal Products), industri perbankan, industri energi, serta industri media dan hiburan (Farzami, Gregory-Allen, Molchanov, \& Sehrish, 2021).

Di Indonesia, Badan Pusat Statistik (BPS) pada pertengahan Juli 2020 melakukan survei terhadap hampir 35.000 pelaku Usaha Menengah Kecil (UMK) dan Usaha Menegah Besar (UMB) dan hasilnya adalah mayoritas pelaku UMK (84,2 \%) dan UMB (82,29 \%) sama-sama melaporkan penurunan pendapatan. Meski hampir semua sektor tertekan oleh pandemi Covid19 sebagian perusahaan masih beroperasi seperti saat sebelum pandemi (BPS, 2020). Tabel 3 menyajikan persentase perusahaan yang masih beroperasi seperti saat belum pandemi.

Tabel 3. Persentase operasional perusahaan berdasarkan sektor usaha Sumber: (BPS, 2020)

\begin{tabular}{clr}
\hline No. & Sektor usaha & $\%$ Operasional perusahaan \\
\hline 1 & Air \& pengelolaan sampah & $77,86 \%$
\end{tabular}


๑ Aldi Akbar ${ }^{\mathbf{1}}$, Karyadi ${ }^{2}$, Budi Rustandi Kartawinata ${ }^{3}$

\begin{tabular}{clc}
2 & Pertanian \& peternakan & $76,63 \%$ \\
3 & Real estate & $76,54 \%$ \\
4 & Listrik \& gas & $76,35 \%$ \\
5 & Perdagangan \& reparasi kendaraan & $69,06 \%$ \\
6 & Pertambangan \& penggalian & $66,91 \%$ \\
7 & Jasa keuangan & $66,33 \%$ \\
8 & Jasa kesehatan & $64,53 \%$ \\
9 & Jasa perusahaan & $59,45 \%$ \\
10 & Transportasi \& pergudangan & $58,75 \%$ \\
\hline
\end{tabular}

Disebutkan pula bahwa penurunan operasional perusahaan tersebut mayoritas berupa pengurangan jam kerja karena hal demikian dinilai sebagai langkah terbaik yang relatif banyak diambil dibandingkan pilihan lain.Turunnya pendapatan perusahaan dikarenakan turunnya permintaan akibat pelanggan atau klien yang terkena Covid-19. Multiplier effect antar sektor usaha tentunya berakibat pula pada kewajiban perusahaan terhadap industri perbankan atau jasa keuangan lainnya.

Relaksasi dan penjadwalan ulang kembali pembayaran pinjaman merupakan salah satu strategi yang diambil agar perusahaan masih tetap dapat beroperasi. Restrukturisasi kredit ini tentunya menjadi tantangan tersendiri bagi industri perbankan karena sebelum pandemi pun pertumbuhan kredit hanya 6,04 \% masihjauh dari yang diinginkan Bank Indonesia yaitu di atas $10 \%$ (Kontan, 2020). Hingga September 2020 telah ada 100 bank yang merestrukturisasi kredit dengan nilai hampir Rp 360 triliun bagi debitur UMKM dan Rp 544,3 triliun bagi debitur non UMKM. Disayangan kebijakan ini tidak bisa menekan NPL, terbukti di kuartal kedua tahun 2020 NPL telah berada di atas 3\%. Bank tentunya melakukan screening untuk menyaring debitur mana yang layak mendapatkan restrukturisasi guna menghindari kerugian dan kenaikan NPL.

Bila melihat demografi penyebaran jumlah kasus Covid-19 di 34 provinsi hingga akhir triwulan III (September 2020) maka hampir 60\% kasus terjadi di pulau Jawa yaitu provinsi DKI Jakarta, Jawa Timur, Jawa Tengah, Jawa Barat, dan Banten (Tribunnews, 2020). Tabel 4 berikut menunjukkan jumlah akumulasi kasus Covid-19 berdasarkan provinsi per akhir September 2020.

Tabel 4. Peta sebaran jumlah kasus Covid-19 per provinsi per akhir September 2020 Sumber: Tribunnews (2020) dan diolah kembali

\begin{tabular}{clrr} 
No. & Provinsi & Jumlah Kasus & Persentase \\
\hline 1 & DKI Jakarta & 67.902 & $25 \%$ \\
2 & Jawa Timur & 42.391 & $16 \%$ \\
3 & Jawa Tengah & 21.004 & $8 \%$ \\
4 & Jawa Barat & 20.131 & $7 \%$ \\
5 & Sulawesi Selatan & 14.982 & $6 \%$ \\
6 & Kalimantan Selatan & 10.080 & $4 \%$ \\
7 & Sumatera Utara & 9.843 & $4 \%$ \\
8 & Bali & 8.389 & $3 \%$ \\
9 & Kalimantan Timur & 7.891 & $3 \%$ \\
10 & Riau & 6.315 & $2 \%$ \\
11 & Papua & 5.763 & $2 \%$ \\
12 & Sumatera Selatan & 5.734 & $2 \%$ \\
13 & Sumatera Barat & 5.363 & $2 \%$ \\
14 & Banten & 5.050 & $2 \%$ \\
15 & Sulawesi Utara & 4.390 & $2 \%$ \\
16 & 19 Provinsi lainnya & 36.111 & $13 \%$
\end{tabular}


Total

271.339

$100 \%$

Dengan mayoritas kasus terbanyak terjadi di pulau Jawa maka berimbas pula pada iklim usaha di provinsi-provinsi tersebut yang turut juga berdampak pada kewajiban pelaku UMK dan UMB terhadap lembaga perbankan. Menurunnya pendapatan hampir di semua lini usaha turut terciptanya gejolak di sektor perbankan baik bank pemerintah pusat, bank pemerintah daerah, dan juga bank swasta nasional terutama dari segi pembiayaan dan penghimpunan dana (Ningsih \& Mahfudz, 2020).

Sejumlah bank pemerintah daerah yang terdaftar di BEI (Bursa Efek Indonesia) juga mengalami gejolak tersebut hal ini terlihat dari rasio NPL yang cenderung bertambah dengan rata-rata di atas NPL industri perbankan. Tabel 5 menunjukkan rasio NPL Gross pada Bank Jawa Barat (BJBR), Bank Jawa Timur (BJTM), dan Bank Banten (BEKS) terhadap rasio NPL industri perbankan. Data diambil dan diolah dari laporan keuangan masing-masing bank daerah di laman Bursa Efek Indonesia pada rentang waktu tiga triwulan sebelum pandemi dan tiga triwulan saat pandemi Covid-19. BJTM dan BEKS menunjukkan rasioNPL di atas rasio NPL industri perbankan dan hanya BJBR yang rasio NPL-nya di bawah NPL industri perbankan.

Tabel 5. NPL bank daerah terhadap NPL industri perbankan.

Sumber: Laporan keuangan dan diolah kembali

\begin{tabular}{lcccc}
\hline \multirow{2}{*}{ Periode } & \multicolumn{4}{c}{ NPL Gross } \\
\cline { 2 - 5 } & BJBR & BJTM & BEKS & Industri Perbankan \\
\hline Triwulan II-2019 & $0,71 \%$ & $3,16 \%$ & $5,02 \%$ & $2,56 \%$ \\
Triwulan III-2019 & $0,64 \%$ & $2,89 \%$ & $5,03 \%$ & $2,59 \%$ \\
Triwulan IV-2019 & $0,51 \%$ & $2,77 \%$ & $5,01 \%$ & $2,68 \%$ \\
Triwulan I-2020 & $1,19 \%$ & $3,35 \%$ & $5,04 \%$ & $2,78 \%$ \\
Triwulan II-2020 & $1,21 \%$ & $4,27 \%$ & $5,69 \%$ & $3,00 \%$ \\
Triwulan III-2020 & $1,15 \%$ & $4,49 \%$ & $6,66 \%$ & $3,19 \%$ \\
\hline
\end{tabular}

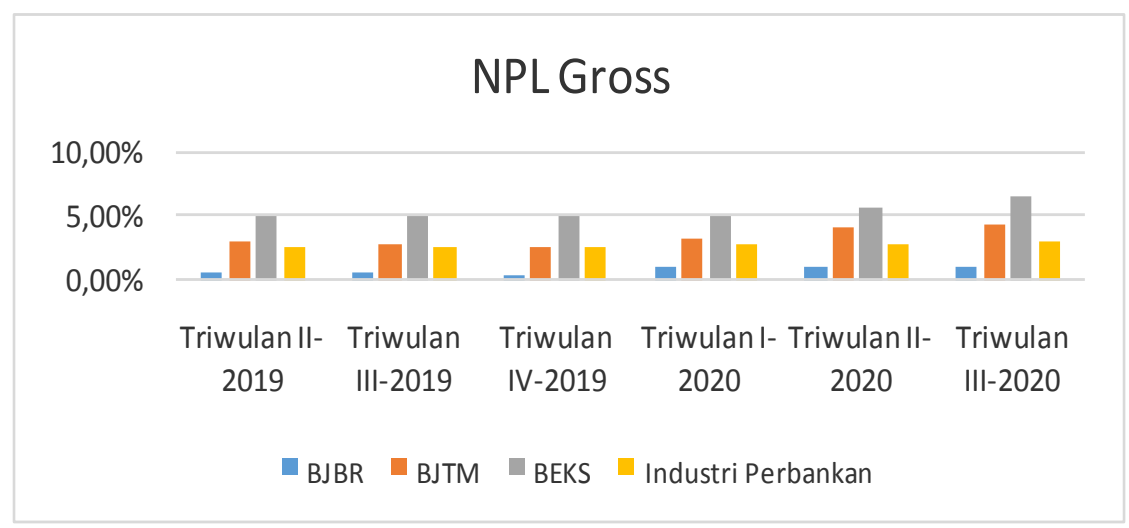

Gambar 1. Grafik NPL bank daerah terhadap NPL industri perbankan

Pada Gambar 1 di atas terlihat bahwa NPL BEKS lebih besar daripada NPL BJBR dan NPL BJTM bahkan melampaui NPL rata-rata industri perbankan. Ini menunjukkan bahwa terjadi gejolak pada sejumlah bank daerah terutama dari sisi rasio NPL sebelum dan saat pandemi Covid-19. Berangkat dari fenomena yang terjadi dan data yang ada maka penelitian ini bertujuan untuk menguji kinerja bank daerah yang terdaftar di BEI pada rentang waktu sebelum dan saat pandemi Covid-19 terjadi melalui proksi non performance loan (NPL).

\section{KAJIAN PUSTAKA}




\subsection{Bank dan Perbankan}

Di era modern saat ini peran bank sangatlah krusial terutama dalam lalu lintas pembayaran, peredaran, penarikan dan pengeluaran uang di masyarakat. Salah satu fungsi bank adalah sebagai perantara dari para penabung dengan pelaku usaha individu atau entitas bisnis yang membutuhkan modal untuk beragam keperluan (Brigham \& Houston, 2015, p. 4), mengedarkan mata uang dan tempat menyimpan beragam barang berharga (Fuady, 2003, p. 13). Tidak hanya sebagai pengumpul dana dan penyalur kredit, peran bank bisa lebih luas lagi yaitu sebagai stabilisator moneter serta dinamisator pertumbuhan ekonomi (Hasibuan, 2002, p. 2). Karena perannya yang sangat penting sebagai perantara jasa keuangan dalam perekonomian suatu negara maka falsafah yang mendasari kegiatan usaha bank adalah public trust atau kepercayaan masyarakat (Pujiyono, 2013, p. 12).

Berdasarkan Undang-Undang RI. No. 10 Tahun 1998 tentang perbankan maka bank dapat dikategorikan ke dalam beberapa golongan yaitu: (1) Berdasarkan jenisnya: (a) Bank Umum, (b) Bank Perkreditan Rakyat; (2) Berdasarkan kepemilikannya: (a) Bank milik Pemerintah, (b) Bank milik Swasta Nasional, (c) Bank milik Swasta Asing, (d) Bank milik Swasta Nasional dan Asing (campuran); (3) Berdasarkan kegiatan usahanya : (a) Bank Devisa, (b)Bank Bukan Devisa; (4) Berdasarkan Kecukupan Modal : (a) Bank Umum, (b) Bank Perkreditan/ Pembiayaan Rakyat.

Antara bank dan perbankan secara definisi berbeda, perbankan adalah segala sesuatu yang menyangkut tentang bank, kelembagaan atau institusi, kegiatan usaha atau entitas bisnis, serta cara dan proses dalam melaksanakaan kegiatan usahanya (Muhammad \& Muniarti, 2000, p. 33; Pujiyono, 2013, p. 10). Fuady (2003, p. 14) menyebutkan bahwa perbankan mengatur segala hal yang terkait dengan masalah lembaga perbankan, hak dan kewajiban, tugas dan tanggung jawab, serta segala aspek yang berkaitan dengan kegiatan perbankan itu sendiri.

\subsection{Kredit}

Kredit memiliki makna kepercayaan dalam arti memberikan atau memperoleh kepercayaan yang melibatkan beberapa unsur di dalamnya yaitu (a) Kepercayaan atau keyakinan dari pihak-pihak yang terlibat; (b) Jangka waktu tertentu yang disepakati; (c) Prestasi yaitu tercapainya kesepakatan perjanjian kredit ; dan (d) Risiko yakni berupa pengikatan jaminan atau agunan (Kasmir, 2002, p. 92; Untung, 2000, p. 1; Pujiyono, 2013, p. 22). Menurut Djumhana (1996, p. 232) tujuan pemberian kredit oleh bank kepada nasabahnya antara lain (1) Motif mencari keuntungan yaitu berupa bunga yang diterima pihak bank/kreditur. Tarif bunga (interest rate) yang diterapkan pihak bank bisa bersifat tetap (fixed rate) atau bunga mengambang/ floating rate(Brigham \& Houston, 2015, p. 578); (2) Membantu usaha nasabah yang memerlukan dana; (3) Membantu pemerintah dalam peningkatan pembangunan dan kesejahteraan rakyat (Ibrahim, 2004, p. 93).

Biaya pinjaman (cost of bank loans) besarnya bervariasi baik untuk nasabah tertentu atau nasabah keseluruhan, suku bunga lebih tinggi diterapkan bagi peminjam yang lebih berisiko atau jumlah pinjamannya kecil dikarenakan adanya biaya tetap dalam membuat dan melayani pinjaman (Brigham \& Houston, 2015, p. 579). Jika sebuah perusahaan dapat memenuhi syarat sebagai "kredit utama" karena ukuran dan kekuatan keuangannya, maka perusahaan tersebut dapat 
meminjam dengan suku bunga utama, yang pada suatu waktu merupakan suku bunga terendah yang dibebankan bank.

\subsection{Non Performing Loan (NPL)}

Non performing loan (NPL) adalah salah satu ukuran untuk menentukan risiko kredit macet. Semakin ketatnya persaingan antar perusahaan bank maka bank pun beramai-ramai meningkatkan pinjaman kepada nasabahnya namun hal ini dapat berakibat pada peningkatan risiko kredit macet. Ada banyak faktor yang mempengaruhi NPL baik ditinjau dari sisi mikroekonomi dan juga makroekonomi.

Kartikasary, et al (2020) dalam penelitian terhadap perusahaan yang tergabung dalam sektor perbankan di Bursa Efek Indonesia menyebutkan bahwa NPL secara bersama dapat dijelaskan oleh faktor mikroekonomi dan makroekonomi. Adapun faktor mikroekonomi yang dimaksud adalah rasio kecukupan modal (CAP), rasio pinjaman terhadap simpanan (loan to deposit,LDR), return on asset (ROA), return on equity (ROE), dan NPL periode sebelumnya. Sedangkan dari faktor makroekonomi yaitu hutang negara (public debt), anggaran fiskal, produk domestik bruto-PDB (gross domestic bruto, GDP), inflasi, dan tingkat pengangguran.

Manakala kondisi suatu negara dalam keadaan resesi maka kredit yang bermasalah pun (NPL) akan meningkat (Ginting, 2017) karena PDB yang melemah sekalipun bagi perusahaan bank yang besar (Fiordelisi, et al, 2011). Dari penelitian terhadap sejumlah bank di Spanyol, Yunani, dan Itali diperoleh hasil bahwa NPL secara makroekonomi dipengaruhi oleh faktor PDB, hutang negara, tingkat suku bunga dan tingkat pengangguran sedangkan secara mikroekonomi dipengaruhi oleh faktor profitabilitas yaitu ROA, dan ROE (Cotugno et al., 2012; Fiordelisi et al.,2011; Louzis etal.,2012; Messai \& Jouini, 2013).

Pada sejumlah negara berkembang, kondisi makroekonomi yang sedang lesu (lambannya pertumbuhan PDB dan angka pengangguran bertambah) juga akan berdampak pada meningkatnya kredit bermasalah. Di samping itu faktor lainnya adalah nilai aset sejumlah bank, nilai tukar terhadap mata uang asing, dan hutang negara juga turut memberikan dampak tambahan terjadinya kredit bermasalah (De Bock \& Demyanets, 2012; Nkusu, 2011). Ozili (2015) dalam penelitiannya pada sejumlah besar bank di Amerika, Eropa, Asia, dan Afrika menyebutkan bahwa guna menekan melonjaknya NPL umumnya pihak bank tidak melakukan diversifikasi pinjaman melainkan penyesuaian terhadap cadangan kerugian pinjaman dan pertumbuhan pinjaman itu sendiri.

Non performing loan (NPL) sebagai salah satu indikator dalam menilai kinerja sektor perbankan tentunya masih sangat relevan untuk digunakan karena dapat mengindikasikan tingkat pertumbuhan dan stabilitas ekonomi baik skala mikro dan makro. Kondisi krisis yang diakibatkan pandemi Covid-19 saat ini dapat berpotensi meningkatkan NPL dan untuk itu Otoritas Jasa Keuangan (OJK) menetapkan nilai NPL sebesar lima persen dan bahkan jika bisa ditingkatkan lagi (Hidayat, 2020). Disebutkan pula bahwa kelonggaran NPL dimaksudkan untuk memberikan keyakinan pada masyarakat untuk tetap menempatkan dananya di bank dan juga memberikan keleluasaan bagi debitur korporasi yang kreditnya bermasalah bahkan sebelum pandemi melanda. 


\section{METODE}

Obyek penelitian ini adalah bank pembangunan daerah yang terdaftar di Bursa Efek Indonesia dengan rentang periode data yang diambil dari kuartal kedua tahun 2019 hingga kuartal ketiga 2020. Metode penelitian ini adalah deskriptif kuantitatif, sifat data berupa data panel, menggunakan data sekunder yang bersumber dari laporan keuangan yang diunduh dari Bursa Efek Indonesia (www.idx.co.id) tiap kuartalnya. Adapun bank pembangunan daerah yang dijadikan sampel dalam penelitian ini adalah BPD Jabar (BJBR), BPD Jatim (BJTM), dan BPD Banten (BEKS).

Analisa kuantitatif berkaitan dengan data numerik, salah satu tingkat pengukuran yang dapat digunakan adalah rasio dan tujuan analisa kuantitatif itu sendiri diantaranya adalah untuk membuat perbandingan (Walliman, 2011). Unit analisis dalam penelitian ini adalah rasio kredit macet gross atau Non Performing Loan Gross (NPL Gross) yang dihitung berdasarkan total kredit bermasalah terhadap total kredit yang diberikan.

Penelitian ini menggunakan teknik analisis uji beda $(\mathrm{t})$ sampel berpasangan (paired sample $\mathrm{t}$ test) karena ingin mengetahui perbedaan NPL Gross sebelum dan saat pandemi Covid-19 pada sejumlah bank pembagunan daerah. Teknik ini menitikberatkan pada keefektifan perlakuan tertentu terhadap sekelompok populasi/ sampel yang sama dan landasan pemikirannya adalah adanya perbedaan rata-rata sebelum dan sesudah perlakuan atau dengan kata lain jika suatu perlakuan tidak memberi pengaruh maka perbedaan rata-ratanya adalah nol (Trihendradi, 2013, p. 97; Gani \& Amalia, 2018, p. 61; Widiyanto, 2013). Paired sample t-test mensyaratkan bahwa data yang diuji haruslah berdistribusi normal dan karena jumlah sampel masing-masing kelompok kurang dari lima puluh (derajat kebebasan (df) <50) maka uji distribusi normal yang digunakan adalah uji normalitas Shapiro-Wilk, data dikatakan berdistribusi normal (uji Shapiro-Wilk) jika nilai Sig. lebih besar dari 0,05 (Santoso, 2017).

Dalam penelitian ini hipotesis yang dirumuskan adalah $\mathrm{HO}=$ tidak terdapat perbedaan yang signifikan antara nilai NPL sebelum pandemi Covid-19 dan nilai NPL setelah pandemi covid-19, H1 = terdapat perbedaan yang signifikan antara nilai NPL sebelum pandemi Covid19 dan nilai NPL setelah pandemi covid-19.

Dasar pengambilan keputusan atau kriteria pengujian adalah $\mathrm{H} 0$ ditolak jika nilai probabilitas (Sig.) $<0,05$ berarti terdapat perbedaan yang signifikan antara nilai NPL sebelum pandemi Covid-19 dan nilai NPL selama pandemi covid-19. H0 tidak ditolak jika nilai probabilitas (Sig.) >0,05 berarti tidak terdapat perbedaan yang signifikan antara nilai NPL sebelum pandemi Covid-19 dan nilai NPL selama pandemi covid-19.

\section{HASIL DAN PEMBAHASAN}

\subsection{Hasil}

Hasil uji normalitas dan statistik desktiptif tersaji dalam tabel 6 berikut.

Tabel 6. Uji normalitas Shapiro-Wilk dan sampel berpasangan

\begin{tabular}{ccc} 
& Sig. (NPL 2019) & Sig. (NPL 2020) \\
\hline Bank JABAR &, 672 &, 637 \\
Bank JATIM &, 583 &, 349 \\
Bank Banten & 1,000 &, 783 \\
\hline N & 9 & 9 \\
Mean & 2,8600 & 3,6722
\end{tabular}


๑Aldi Akbar ${ }^{1 *}$, Karyadi², Budi Rustandi Kartawinata ${ }^{3}$

\begin{tabular}{ccc} 
St.dev & 1,90950 & 2,07920 \\
Std.error mean &, 63650 &, 69307 \\
\hline
\end{tabular}

Merujuk pada tabel 6 diperoleh informasi objektif bahwa seluruh sampel memberikan hasil signfikansi di atas 0,05 dan tidak ada yang bernilai di bawahnya. Hal tersebut mengindikasikan dalam dataset penelitian seluruh sampel berdistribusi normal. Rata-rata nilai non performing loan sebelum pandemi Covid-19 (NPL 2019) adalah 2,86\% dan rata-rata nilai non performing loan saat pandemi Covid-19 (NPL 2020) adalah 3,672 \%. Rata-rata standar error NPL 2019 adalah 0,636 \% dan rata-rata standar error NPL 2020 adalah 0,693\%. JIka nilai rata-rata standar error pada masing-masing kelompok sampel diperhitungkan maka ratarata nilai NPL 2019 berkisar 2,86 \% 0,636 \% dan rata-rata nilai NPL 2020 berkisar 3,672 \% $\pm 0,693 \%$. Dengan demikian terdapat perbedaan nilai NPL sebelum dan saat pandemi meski besarannya relatif tidak terlalu besar. Hal ini dapat dilihat pada gambar 2 berikut.

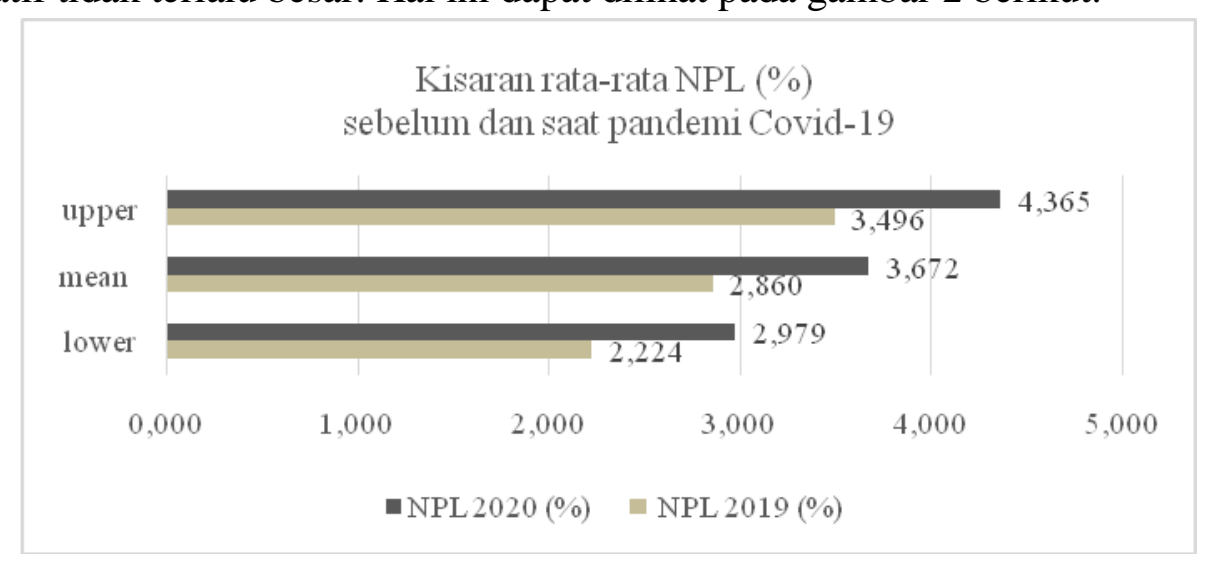

Gambar 2. Perbedaan rata-rata NPL sebelum dan saat pandemi Covid-19

Hasil uji korelasi sampel berpasangan dan uji t sampel berpasangan (paired sample $t$ test)tersaji pada tabel 7 berikut.

Tabel 7. Ringkasan korelasi dan Uji t sampel berpasangan(paired sample t-test)

\begin{tabular}{|c|c|c|c|c|c|c|}
\hline \multirow{2}{*}{ Sampel berpasangan } & \multicolumn{2}{|c|}{$\begin{array}{c}\text { Korelasi sampel } \\
\text { berpasangan }\end{array}$} & \multicolumn{4}{|c|}{ Uji t Sampel Berpasangan } \\
\hline & Correlation & Sig. & Mean & Std. Error Mean & $t$ & Sig. (2-tailed) \\
\hline NPL $2020(\%)$ - NPL $2019(\%)$ & 0,955 & 0,000 & 0,812 & 0,207 & 3,924 & 0,004 \\
\hline
\end{tabular}

Merujuk pada tabel 7 diperoleh informasi objektif sebagai berikut (a) Uji korelasi pada sampel berpasangan menunjukkan bahwa nilai korelasi NPL sebelum dan saat pandemi Covid19 sebesar 0,955 dengan tingkat signifikansi 0,000. Ini berarti bahwa ada hubungan antara kedua sampel dengan tingkat hubungan/ korelasi sangat erat dan signifikan, adapun indikatornya adalah nilai signifikansi di bawah 0,05.; (b) Nilai mean sebesar 0,812 \% menunjukkan selisih atau perbedaan nilai NPL sebelum dan saat pandemi Covid-19. Nilai NPL saat pandemi lebih besar daripada nilai NPL sebelum pandemi Covid-19. Standar error mean sebesar 0,207 \% lebih kecil daripada nilai mean (0,812 \%). Komparasi kedua angka ini menujukkan bahwa secara inferensial terdapat perbedaan nilai NPL sebelum dan saat pandemi Covid-19.; (c) Nilai t pada uji sampel sampel berpasangan menunjukkan angka 3,924 dengan tingkat signifikansi 0,004. Angka ini menunjukkan bahwa H0 ditolak dan indikatornya adalah signifikan $\mathrm{t}$ lebih kecil dari tingkat alpha $(0,05 / 2=0,025)$. Sehingga disimpulkan bahwa 
terdapat perbedaan yang signifikan nilai NPL pada bank pembangunan daerah sebelum pandemi Covid-19 dan saat pandemi Covid-19.

Pembahasan

Hasil uji hipotesis menunjukkan bahwa pandemi Covid-19 memberikan dampak yang signifikan terhadap risiko kredit macet (NPL) pada sejumlah bank pembangunan daerah. Turunnya pendapatan dari para nasabah pelaku UMK $(84,2 \%)$ dan UMB $(82,29 \%)$ berimbas pada kemampuan bayar terhadap kredit yang telah dikucurkan pihak perbankan jadi bisa dikatakan dampaknya berbeda pada tiap segmen nasabah. Menurut Ikhsan (2020) untuk segmen nasabah korporasi, proyeksi revenue industri perbankan sebelum pandemi Covid-19 mencapai Rp 90 triliun namun sejak kemunculan pandemi Covid-19 diprediksi turun menjadi Rp 81 triliun sampai Rp 84 triliun jadi ada penurunan sekitar 7\% - 10\%. Untuk segmen nasabah UMK, proyeksi revenue industri perbankan sebelum ada pandemi Covid-19 diprediksi mencapai Rp 77 triliun. Pasca kemunculan pandemi Covid-19 diprediksi turun menjadi Rp 68 triliun sampai Rp 71 triliun, jadi ada penurunan sekitar 7\% - 11\%. Pada segmen nasabah mikro, proyeksi revenue industri perbankan sebelum ada pandemi Covid-19 diprediksi mencapai Rp 46 triliun. Pasca kemunculan pandemi Covid-19 diprediksi turun menjadi Rp 37 triliun sampai Rp 39 triliun, secara persentase terjadi penurunan 14\% - 19\%. Sedangkan pada segmen nasabah ritel, proyeksi revenue industri perbankan pada tahun ini sebelum pandemiCovid-19 diprediksi mencapai Rp 241 triliun. Pasca kemunculan Covid-19 diprediksi turun menjadi Rp 214 triliun sampai Rp 222 triliun, penurunan terjadi sekitar 8\% - 11\%. Namun demikian secara umum industri perbankan telah menerapkan transaksi digital guna menghadapi Revolusi Industri 4.0 sekaligus sebagai katalisator transformasi digital bagi nasabahnya.

Bila melihat rasio profitabilitas dengan proxyreturn on asset (ROA) maka terlihat bahwa baik Bank Jabar (BJBR), Bank Jatim (BJTM) maupun Bank Banten (BEKS) mengalami tren penurunan terutama saat pandemi Covid-19 (tabel 8).

Tabel 8. ROA dan NPL bank pembangunan daerah sebelum dan saat pandemi Covid-19. Sumber: Bursa Efek Indonesia (diolah kembali)

\begin{tabular}{lccc|ccc}
\hline \multirow{2}{*}{ Periode } & \multicolumn{3}{c}{ NPL Gross } & \multicolumn{3}{c}{ ROA } \\
\cline { 2 - 7 } & BJBR & BJTM & BEKS & BJBR & BJTM & BEKS \\
\hline Triwulan II-2019 & $0,71 \%$ & $3,16 \%$ & $5,02 \%$ & $0,66 \%$ & $1,18 \%$ & $-1,11 \%$ \\
Triwulan III-2019 & $0,64 \%$ & $2,89 \%$ & $5,03 \%$ & $0,92 \%$ & $1,58 \%$ & $-1,40 \%$ \\
Triwulan IV-2019 & $0,51 \%$ & $2,77 \%$ & $5,01 \%$ & $1,33 \%$ & $1,80 \%$ & $-1,78 \%$ \\
Triwulan I-2020 & $1,19 \%$ & $3,35 \%$ & $5,04 \%$ & $0,34 \%$ & $0,53 \%$ & $-0,39 \%$ \\
Triwulan II-2020 & $1,21 \%$ & $4,27 \%$ & $5,69 \%$ & $0,68 \%$ & $0,93 \%$ & $-1,46 \%$ \\
Triwulan III-2020 & $1,15 \%$ & $4,49 \%$ & $6,66 \%$ & $0,89 \%$ & $1,43 \%$ & $-2,20 \%$ \\
\hline
\end{tabular}

Untuk Bank Jabar (BJBR) dan Bank Jatim (BJTM) sebelum pandemi Covid-19 mengalami kenaikan profitabilitas sejak triwulan II 2019 hingga triwulan IV 2020 namun kemudian sempat terkontraksi di triwulan I 2020 untuk selanjutnya perlahan mulai bangkit kembali mengalami kenaikan meski kinerja kedua bank tersebut masih di bawah kinerja ratarata industri perbankan yang berkisar 2,11\% - 2,17 \% (OJK, 2020). Sedangkan pada Bank Banten (BEKS) mengalami dampak paling parah yakni sebelum pandemi Covid-19 melanda sudah berada di bawah rata-rata

kinerja industri perbankan dan manakala pandemi terjadi semakin memperburuk keadaan terutama hingga triwulan III 2020 walau sebenarnya di triwulan I 2020 sempat mengalami 
peningkatan kinerja dibandingkan tahun 2019. Berkurangnya peneriman dari sektor penyaluran kredit dari para nasabah, hambatan dalam usaha dari pelaku usaha, dan adanya kebijakan restrukturisasi dari Otoritas Jasa Keuangan turut memperkecil penerimaan kas (Wangsit Supeno, 2020). Menurunnya ROA pada ketiga bank tersebut berdampak pada meningkatnya NPL mengingat secara mikro NPL dipengaruhi oleh faktor ROA (Cotugno et al., 2012; Fiordelisi et al.,2011; Louzis etal.,2012; Messai \& Jouini, 2013; Kartikasary, et al.,2020).

Secara makroekonomi perubahan NPL juga turut dipengaruhi oleh kondisi perekonomian yang tengah resesi. Tabel 9 menunjukkan nilai NPL Gross Bank Jabar (BJBR), Bank Jatim (BJTM), dan Bank Banten (BEKS) dengan perbandingannya terhadap faktor makroekonomi berupa inflasi, pertumbuhan Produk Domestik Bruto (PDB), dan Tingkat Pengangguran Terbuka (TPT).

Tabel 9. NPL bank pembangunan daerah dan faktor makroekonomi. Sumber: Bursa Efek Indonesia (diolahkembali), BPS (2019 \& 2020)

\begin{tabular}{lcccccc}
\hline \multirow{2}{*}{ Periode } & \multicolumn{3}{c}{ NPL Gross } & \multirow{2}{*}{ Inflasi } & $\begin{array}{c}\text { Pertumbuhan } \\
\text { PDB }\end{array}$ & \multirow{2}{*}{ TPT } \\
\cline { 2 - 4 } BJBR & BJTM & BEKS & & $5,07 \%$ & $5,01 \%$ \\
Triwulan II-2019 & $0,71 \%$ & $3,16 \%$ & $5,02 \%$ & $3,14 \%$ & $3,06 \%$ & $5,23 \%$ \\
Triwulan III-2019 & $0,64 \%$ & $2,89 \%$ & $5,03 \%$ & $3,40 \%$ & $-1,74 \%$ & $5,28 \%$ \\
Triwulan IV-2019 & $0,51 \%$ & $2,77 \%$ & $5,01 \%$ & $2,95 \%$ & & $4,99 \%$ \\
Triwulan I-2020 & $1,19 \%$ & $3,35 \%$ & $5,04 \%$ & $2,87 \%$ & $-2,41 \%$ & $8,40 \%$ \\
Triwulan II-2020 & $1,21 \%$ & $4,27 \%$ & $5,69 \%$ & $2,27 \%$ & $-4,19 \%$ & $7,07 \%$ \\
Triwulan III-2020 & $1,15 \%$ & $4,49 \%$ & $6,66 \%$ & $1,43 \%$ & $5,05 \%$ & \\
\hline
\end{tabular}

NPL ketiga bank tersebut yang secara umum mengalami tren kenaikan tiap triwulannya tidak diiringi dengan laju inflasi yang justru secara makro dapat ditekan hingga di bawah 3\% meski pandemi tengah berlangsung. Pemerintah sendiri mentargetkan sasaran inflasi untuk tiga tahun berturut-turut sebesar 3,5\% di tahun 2019, 3\% masing-masing di tahun 2020 dan 2021, hal yang demikian juga sudah tertuang dalam Peraturan Menteri Keuangan No.124/PMK.010/2017. Harapannya adalah inflasi tetap dapat ditekan (rendah) dan stabil serta menjadi rujukan bagi masyarakat dalam berkegiatan perekonomian. Meski inflasi dapat ditekan namun turunnya pendapatan bagi sebagian besar masyrakat dan juga pelaku usaha tetap memberikan dampak bagi perbankan terutama pembayaran kredit baik pokok pinjaman serta bunga pinjaman.

Pandemi Covid-19 memberikan imbas pada pertumbuhan PDB, terlihat bahwa tren pertumbuhan PDB mengalami penurunan hingga puncaknya di triwulan II 2020 yakni menyentuh angka $-4,19 \%$ yang mana di periode ini mulai pertama kalinya diterapkan lockdown atau Pembatasan Sosial Berskala Besar (PSBB) di hampir banyak wilayah di Indonesia (Mashabi, 2020). Menurut data BPS (2020), pada triwulan II 2020 laju pertumbuhan PDB berdasarkan lapangan usaha maka hanya lapangan usaha pertanian, kehutanan dan perikanan serta lapangan usaha pengadaan air, pengelolaan sampah, limbah dan daur ulang yang menunjukkan angka positif yakni berturut sebesar 16,24\% dan 1,28\%. Sedangkan laju pertumbuhan PDB berdasarkan lapangan usaha jasa keuangan dan asuransi menunjukkan angka sebaliknya yaitu $-10,30 \%$. Namun demikian pada triwulan III 2020 keadaan sudah mulai membaik yakni dengan laju pertumbuhan PDB berdasarkan lapangan usaha seluruhnya menunjukkan angka positif khususnya pada sektor jasa keuangan dan asuransi sebesar 2,59\%. Namun demikian untuk ketiga bank yakni Bank Jabar, Bank Jatim, dan Bank Banten 
membaiknya laju pertumbuhan PDB di lapangan usaha jasa keuangan dan asuransi belum memberikan sentimen positif terhadap kinerja NPL karena bisa jadi, khusus sektor perbankan, penyaluran kredit pada UKM yang secara persentase lebih besar dan efek pandemi Covid-19 ini memberikan dampak yang besar pula pada UKM (Wangsit Supeno, 2020).

Pilihan yang diambil oleh pelaku usaha dengan menyesuaikan jam kerja karyawannya dengan menerapkan work from home, pengurangan jumlah karyawan bahkan memberhentikan permanen adalah imbas lanjutan dari pandemi Covid-19 ini. Sebelum pandemi melanda Tingkat Pengangguran Terbuka (TPT) cenderung stagnan di angka 5\% bahkan sempat turun di awal pandemi triwulan I 2020 yakni 4,99\%. Namun puncaknya terjadi di triwulan II 2020 yakni angka TPT melonjak drastis sebesar 8,40\%. Meski akhirnya di triwulan III 2020 angka TPT mulai menurun menjadi 7,07\%. Pengurangan karyawan hingga munculnya pengangguran baru efek dari pandemi dilakukan agar pelaku usaha tetap mampu bertahan dengan memangkas pengeluaran atau beban operasional dari sisi gaji/upah karyawan. Bahkan menurut BPS (2020) dari 203,97 juta penduduk usia kerja sebanyak 14,28\% penduduk usia kerja yang terdampak Covid-19. Manakala pelaku usaha tidak mengambil kebijakan yang tidak disukai ini maka akan membebankan arus kas perusahaan dalam membayar kewajiban pinjaman ke bank yang pada akhirnya bank pun akan mengalami penurunan pendapatan dan NPL yang cenderung bertambah. Kondisi yang demikian masih selaras dengan hasil penelitian yang dilakukan Cotugno et al. (2012), Fiordelisi et al. (2011), Ginting (2017), Louzis et al. (2012), Messai \& Jouini (2013).

\section{KESIMPULAN}

Dari hasil penelitian berikut penjelasan di atas dapat disimpulkan bahwa non performing loan (NPL) pada ketiga bank pembangunan daerah (Bank Jabar, Bank Jatim, Bank Banten) yang terdaftar di BEI mengindikasian ikut terdampak pandemi Covid-19. Hal ini tercermin dari pergerakan nilai NPL yang cenderung bertambah terutama saat pandemi mulai menerpa Indonesia di triwulan II dan III 2020. NPL yang cenderung meningkat ini dikarenakan (secara mikroekonomi) pendapatan bank yang juga terkontraksi dari sisi penerimaan pembayaran pinjaman nasabah yang juga bermasalah baik itu nasabah kategori pelaku usaha baik usaha kecil maupun besar dan juga nasabah kategori non pelaku usaha. Kondisi demikian didukung pula dengan indikator makroekonomi terutama pertumbuhan PDB dan Tingkat Pengangguran Terbuka (TPT) terkecuali inflasi yang mana untuk laju inflasi berhasil dikendalikan oleh pengambil kebijakan.

Dari penelitian ini sampel yang digunakan sangatlah kecil dan untuk itu dalam penelitian berikutnya sebaiknya cakupan sampel diperluas hingga ke seluruh perusahaan bank yang ada terutama yang telah terdaftar di BEI. Di samping itu juga rentang waktu yang diambil sebaiknya dari awal tahun 2019 hingga akhir tahun 2020 agar didapat data yang lebih komprehensif.

\section{REFERENSI}

Abdi, M. N. (2020). Krisis Ekonomi Global dari Dampak Penyebaran Virus Corona (Covid19). AkMen Jurnal Ilmiah, 17(1), 90-98. 
ADB. (2020, Desember 10). Asian Development Bank. Retrieved Maret 21, 2021, from www.adb.org: https://www.adb.org/news/developing-asia-contract-2020-grow-2021

BPS. (2020). Analisis Hasil Survei Dampak Covid-19 Terhadap Pelaku Usaha. BPS, Subdirektorat Indikator Statistik. Jakarta: BPS RI. Retrieved Maret 21, 2021, from https://www.bps.go.id/publication/2020/09/15/9efe2fbda7d674c09ffd0978/analisishasil-survei-dampak-covid-19-terhadap-pelaku-usaha.html

Brigham, E. F., \& Houston, . F. (2015). Fundamentals of Financial Management (14 ed.). Boston, USA: Cengage Learning.

Chen, H. C., \& Yeh, C. W. (2021). Global financial crisis and COVID-19: Industrial reactions. Finance Research Letters. https://doi.org/10.1016/j.frl.2021.101940

Cotugno, M., Stefanelli, V., \& Torluccio, G. (2012). Bank Intermediation Models and Portfolio Default Rates: What's the Relation? SSRN Electronic Journal. https://doi.org/10.2139/ssrn.1662888

De Bock, M. R., \& Demyanets, M. A. (2012). Bank asset quality in emerging markets: Determinants and spillovers. International Monetary Fund.

Djumhana, M. (1996). Hukum Perbankan di Indonesia. Bandung: Citra Aditya Bhakti.

Dong, Y., Dong, Y., Mo, X., Hu, Y., Qi, X., Jiang, F., ... Tong, S. (2020). Epidemiology of COVID-19 among children in China. Pediatrics. https://doi.org/10.1542/peds.2020-0702

Dzulfaroh, A. N. (2020, November 02). PT. Kompas Cyber Media. Retrieved Maret 20, 2021, from Kompas.com: https://www.kompas.com/tren/read/2020/11/02/180600865/

perjalanan-8-bulan-pandemi-virus-corona-di-indonesia?page=all

Farzami, Y., Gregory-Allen, R., Molchanov, A., \& Sehrish, S. (2021). COVID-19 and the liquidity network. Finance Research Letters. https://doi.org/10.1016/j.frl.2021.101937

Fiordelisi, F., Marques-Ibanez, D., \& Molyneux, P. (2011). Efficiency and risk in European banking. Journal of Banking and Finance, 35(5). https://doi.org/10.1016/j.jbankfin.2010.10.005

Fuady, M. (2003). Hukum Perbankan Modern Buku Kesatu. Bandung: Citra Aditya Bakti.

Gani, I., \& Amalia, S. (2018). Alat Analisis Data: Aplikasi statsitik untuk penelitian bidang ekonomi dan sosial. Yogyakarta: Penerbit ANDI.

Ginting, A. M. (2017). PENGARUH MAKROEKONOMI TERHADAP NON PERFORMING LOAN (NPL) DI INDONESIA: STUDI NON PERFORMING LOAN PERBANKAN. Jurnal Ekonomi Dan Kebijakan Publik, 7(2). https://doi.org/10.22212/jekp.v7i2.669 
Gopinath, G. (2020, October 12). International Monetary Fund. Retrieved Maret 20, 2021, from www.imf.org: https://www.imf.org/en/News/Articles/2020/10/13/tr101320transcript-of-october-2020-world-economic-outlook-press-briefing

Hasibuan, M. S. (2002). Dasar-dasar Perbankan. Jakarta: PT. Bumi Aksara.

Hidayat, F. (Ed.). (2020, September 16). Warta Ekonomi. Retrieved Maret 28, 2021, from wartaekonomi.co.id: $\mathrm{t}$

Ibrahim, J. (2004). Mengupas Tuntas Kredit Komersial dan Konsumtif Dalam Perjanjian Kredit Bank (Perspektif Hukum dan Ekonomi). Bandung: Mandar Maju.

Ikhsan, M. (2020, Juli 22). Turning Pandemic Into Opportunity. Maybank Indonesia Webinar Economic Outlook 2020. Jakarta, DKI, Indonesia: Maybank Indonesia .

Kartikasary, M., Marsintauli, F., Serlawati, E., \& Laurens, S. (2020). Factors affecting the nonperforming loans in Indonesia. Accounting, 6(2). https://doi.org/10.5267/j.ac.2019.12.003

Kasmir. (2002). Bank dan Lembaga Keuangan Lainnya (6 ed.). Jakarta: PT. Raja Grafindo Persada.

Kontan. (2020, Oktober 20). Kontan.co.id. Retrieved Maret 22, 2021, from keuangan.kontan.co.id: https://keuangan.kontan.co.id/news/begini-nasib-industriperbankan-di-saat-pandemi-virus-corona-covid-19?page=all

Louzis, D. P., Vouldis, A. T., \& Metaxas, V. L. (2012). Macroeconomic and bank-specific determinants of non-performing loans in Greece: A comparative study of mortgage, business and consumer loan portfolios. Journal of Banking and Finance, 36(4). https://doi.org/10.1016/j.jbankfin.2011.10.012

Mashabi, S. (2020, April 20). Kompas Cyber Media. (Krisiandi, Editor) Retrieved April 06, 2021, from Kompas.com: https://nasional.kompas.com/read/2020/04/20/05534481/daftar-18-daerah-yangterapkan-psbb-dari-jakarta-hingga-makassar?page=all

McKibbin, W., \& Vines, D. (2020). Global macroeconomic cooperation in response to the COVID-19 pandemic: a roadmap for the G20 and the IMF. Oxford Review of Economic Policy, 36(Supplement_1), S297-S337. https://doi.org/10.1093/oxrep/graa032

Messai, A. S., \& Jouini, F. (2013). Micro and macro determinants of non-performing loans. International Journal of Economics and Financial Issues, 3(4).

Muhammad, A., \& Muniarti, R. (2000). Segi Hukum Lembaga Keuangan Dan Pembiayaan. Bandung: PT. Citra Aditya Bakti.

Ningsih, M. R., \& Mahfudz, M. S. (2020). DAMPAK PANDEMI COVID-19 TERHADAP 
MANAJEMEN INDUSTRI PERBANKAN SYARIAH: ANALISIS KOMPARATIF. POINT, 2(1). https://doi.org/10.46918/point.v2i1.576

Nkusu, M. (2011). Nonperforming loans and macrofinancial vulnerabilities in advanced economies. IMF Working Papers, 1-27.

OJK. (2019). Statistik Perbankan Indonesia. Jakarta: Otoritas Jasa Keuangan.

OJK. (2020). Statistik Perbankan Indonesia. Jakarta: Otoritas Jasa Keuangan.

Organization, W. H. (n.d.). Critical preparedness, readiness and response actions for COVID19: interim guidance, 22 March 2020. Geneva PP - Geneva: World Health Organization. Retrieved from https://apps.who.int/iris/handle/10665/331511

Ozili, P. K. (2015). How Bank Managers Anticipate Non-Performing Loans Evidence from Europe, US, Asia and Africa. Applied Finance and Accounting, 1(2). https://doi.org/10.11114/afa.v1i2.880

Pak, A., Adegboye, O. A., Adekunle, A. I., Rahman, K. M., McBryde, E. S., \& Eisen, D. P. (2020). Economic Consequences of the COVID-19 Outbreak: the Need for Epidemic Preparedness. Frontiers in Public Health, 8. https://doi.org/10.3389/fpubh.2020.00241

Prayogo, C. (2020, Oktober 19). Warta Ekonomi. Retrieved Maret 20, 2021, from WartaEkonomi.co.id: https://www.wartaekonomi.co.id/read309848/dampak-pandemicovid-19-terhadap-perekonomian-dunia-infografis

Pujiyono. (2013). Pentingnya Mediasi Perbankan. Solo: CV. Indotama Solo.

Purwanto, A. (2020, Agustus 29). KompasPedia. Retrieved Maret 21, 2021, from kompaspedia.kompas.id: https://kompaspedia.kompas.id/baca/paparan-topik/kebijakanfiskal-moneter-dan-jasa-keuangan-untuk-mengatasi-dampak-covid-19-di-indonesia

Rose-Redwood, R., Kitchin, R., Apostolopoulou, E., Rickards, L., Blackman, T., Crampton, J., ... Buckley, M. (2020). Geographies of the COVID-19 pandemic. Dialogues in Human Geography, 10(2). https://doi.org/10.1177/2043820620936050

Santoso, S. (2017). Menguasai Statistik dengan SPSS 24. Jakarta: Elex Media Komputindo.

Tribunnews. (2020, September 26). Tribun Network. Retrieved Maret 25, 2021, from Tribunnews.com: https://www.tribunnews.com/corona/2020/09/26/update-corona-26september-2020-dan-sebarannya-per-provinsi-total-kasus-capai-271339?page=all

Trihendradi, C. (2013). Langkah mudah menguasai SPSS 21. Yogyakarta: Penerbit ANDI.

Untung, B. (2000). Kredit Perbankan di Indonesia. Yogyakarta: Andi.

Walliman, N. (2011). Research methods: the basics. New York: Routledge. 
○Aldi Akbar ${ }^{1 *}$, Karyadi², Budi Rustandi Kartawinata ${ }^{3}$

Wangsit Supeno, I. H. (2020). Kinerja Kredit Terhadap Profitabilitas Bpr Pada Masa Pandemi Covid-19. Journal of Chemical Information and Modeling, 53(9).

Widiyanto, M. A. (2013). Statistika Terapan. Jakarta: Elex Media Komputindo.

Yamali, F. R. (2020). Dampak Covid-19 Terhadap Ekonomi Indonesia. Ekonomis: Journal of Economics and Business, 4(2), 384-388. 